\title{
Vasopressin responders have a high prevalence of hypertension and insulin resistance in spite of a lower secretion of cortisol in subclinical Cushing's syndrome
}

\author{
SAWAKO SUZUKI, DAIGAKU UCHIDA, HISASHI KOIDE, KEIKO SUYAMA, TOMOAKI TANAKA, \\ YOSHIHIKO NOGUCHI, YASUSHI SAITO and ICHIRO TATSUNO

\begin{abstract}
Department of Clinical Cell Biology, Graduate School of Medicine, Chiba University; Department of Clinical Endocrinology and Metabolism, Chiba University Hospital, Chiba, Japan
\end{abstract}

Received September 19, 2008; Accepted November 6, 2008

DOI: 10.3892/mmr_00000071

\begin{abstract}
The hyper-responsiveness of plasma cortisol to vasopressin has been reported in patients with ACTHindependent bilateral macronodular adrenocortical hyperplasia (AIMAH) and in certain cases of Cushing's adenomas with overexpression of $\mathrm{V} 1 \mathrm{a}$ receptors in the adrenal gland. We previously reported a high prevalence of the adrenal hyperresponsiveness of plasma cortisol to vasopressin (vasopressin responders) in Japanese patients with Cushing's syndrome (CS), in which vasopressin responders had low autonomous cortisol secretion and were diagnosed as having subclinical CS. In the present study, we aimed to evaluate the pathophysiological significance of vasopressin responsiveness in patients with subclinical CS in terms of hormonal secretion and metabolic abnormalities. We compared 14 vasopressin responders and 13 non-responders with subclinical CS, admitted to Chiba University Hospital between 1999 and 2007. Among these patients, the vasopressin responders were found to have lower plasma cortisol levels than non-responders at midnight $(\mathrm{P}<0.05)$ and in the morning following overnight dexamethasone suppression at $1 \mathrm{mg}(\mathrm{P}<0.05)$. On the other hand, they showed a significantly higher frequency of hypertensive complications than non-responders. In addition, according to $75 \mathrm{~g}$-OGTT the vasopressin responders had significantly higher levels of plasma insulin at $60 \mathrm{~min}$ than the non-responders, and their cortisol response to vasopressin had a significantly positive association with HOMA-IR ( $\mathrm{r}=0.671$, $\mathrm{P}<0.05)$. A high expression level of $\mathrm{V} 1$ a receptor mRNAs
\end{abstract}

Correspondence to: Dr Ichiro Tatsuno, Department of Clinical Cell Biology, Graduate School of Medicine, Chiba University, 1-8-1 Inohana, Chuo-ku, Chiba 260-8670, Japan

E-mail: ichiro-tatsuno@faculty.chiba-u.jp

Abbreviations: AIMAH, ACTH-independent bilateral macronodular adrenocortical hyperplasia; CS, Cushing's syndrome; QRT-PCR, quantitative real-time PCR

Key words: vasopressin, Cushing's syndrome, V1a receptor, insulin resistance, metabolic disease was observed in the resected adrenal glands of vasopressin responders with AIMAH and unilateral adenomas. Though vasopressin responders with subclinical CS had lower autonomous cortisol secretion, they had a high prevalence of hypertension, in which insulin resistance was closely correlated with cortisol response to vasopressin.

\section{Introduction}

Vasopressin is produced in the hypothalamus and secreted from the posterior lobe of the pituitary gland. It is known to modulate the water metabolism by increasing free water reabsorption via the $\mathrm{V} 2$ receptor, located in the renal collecting duct (1). It is an important factor in the regulation of cortisol secretion, mainly by ACTH stimulation via the V1b (or V3) receptor (2), and also by direct cortisol secretion from the adrenal cortex via the V1a (or V1) receptor (V1aR) (3).

Recently, the adrenal hyper-responsiveness of plasma cortisol to vasopressin independently of ACTH secretion has been reported in the majority of cases of ACTH-independent bilateral macronodular adrenocortical hyperplasia (AIMAH), a condition characterized by bilateral nodular adrenocortical hyperplasia and the hyper-secretion of cortisol, as well as in some cases of Cushing's syndrome (CS) with adrenal adenomas (4-9). Our and other reports have demonstrated that, in these cases, the action of vasopressin is mediated via the eutopic overexpession of the V1a receptor (10-15). We also reported a high prevalence of the adrenal hyper-responsiveness of plasma cortisol to vasopressin in adrenal nodule(s), and that all vasopressin responders with CS showed low autonomous cortisol secretion, diagnosed as subclinical CS (9). However, the clinical significance of vasopressin responders among patients with CS has not been clarified. We aimed to evaluate the pathophysiological significance of vasopressin response in patients with CS, especially subclinical CS, in terms of hormonal secretion and metabolic abnormalities.

\section{Materials and methods}

Subjects. Between 1999 and 2007, we performed the vasopressin-loading test and endocrinological evaluation in 71 consecutive patients with adrenal nodule(s), except pheochromocytomas, after obtaining written informed consent. 
Patients were included after the absence of factors known to affect the dexamethasone suppression test (drugs, alcoholism, obvious depression, pregnancy) was confirmed. Ten patients who failed to suppress plasma ACTH during the vasopressinloading test were excluded. A total of 61 patients with adrenal nodule(s) were finally analyzed. This study was approved by the Ethics Committee of Chiba University. Overt CS was determined in patients with signs or symptoms of excess hormones, suppressed plasma ACTH, increased 24-h urinary free cortisol and high plasma cortisol not suppressed below $138 \mathrm{nmol} / \mathrm{l}(5 \mu \mathrm{g} / \mathrm{dl})$ with overnight dexamethasone of 1 or $8 \mathrm{mg}$. Subclinical CS was determined in patients with no signs or symptoms of excess hormones, subnormal suppression following overnight dexamethasone with $1 \mathrm{mg}$ (>50 nmol/l; $1.8 \mu \mathrm{g} / \mathrm{dl}$ ) and normal 24-h urinary free cortisol (16-18). There were 27 patients diagnosed with subclinical CS, 14 of which were vasopressin responders. In this study, we compared the 14 vasopressin responders with the 13 nonresponders with subclinical CS.

Basal endocrinological evaluation. Plasma cortisol and ACTH levels at 08:00, 12:00, 16:00, 20:00 and 24:00 h, 24-h excretion of urinary free cortisol, and plasma dehydroepiandrosterone sulfate (DHEAS), aldosterone and renin levels were measured.

Dexamethasone suppression test and vasopressin-loading test. The low- and high-dose dexamethasone suppression test with the vasopressin-loading test was performed overnight in all subjects according to the following protocol: briefly, $1 \mathrm{mg}$ of dexamethasone was administered orally at 23:00 h (overnight 1-mg dexamethasone test), then a plasma cortisol sample was obtained at 08:00 $\mathrm{h}$ the next morning. On that same day, $2 \mathrm{mg}$ of dexamethasone was administered orally 4 times (every $6 \mathrm{~h}$ for one day) (overnight 8-mg dexamethasone test). A plasma cortisol sample was obtained at 08:00 $\mathrm{h}$ the next morning followed by the vasopressin-loading test under the suppression of endogenous ACTH response by high-dose dexamethasone. The test was performed after $60 \mathrm{~min}$ of rest in the supine position following overnight fasting. AVP (5 U) (Sankyo Co., Tokyo, Japan) was administered subcutaneously, and blood samples were obtained at $0,15,30,60,90$ and $120 \mathrm{~min}$ (15). As in previous studies $(6,8)$, patients with a cortisol response to vasopressin of $>50 \%$ compared to basal levels were defined as vasopressin responders.

Physical and biochemical evaluation. Blood pressure was measured by auscultation after 20 min of rest in a supine position (19). The average value of 3 measurements was used. Hypertension was diagnosed when systolic pressure was above $140 \mathrm{~mm} \mathrm{Hg}$ or diastolic pressure was above $90 \mathrm{~mm} \mathrm{Hg} \mathrm{(20),}$ or when the patient was already receiving antihypertensive treatment.

HbA1c and fasting plasma glucose were measured in all subjects. The oral glucose tolerance test (OGTT) was performed in patients not diagnosed with diabetes mellitus. The diagnosis of impaired glucose tolerance or diabetes mellitus (DM) was made according to the American Diabetes Association guidelines (21). The homeostatis model assessment for insulin resistance (HOMA-IR) was calculated as fasting insulin $(\mu \mathrm{U} / \mathrm{ml}) \mathrm{x}$ fasting glucose $(\mathrm{mmol} / \mathrm{l}) / 22.5(22)$.
Dyslipidemia was diagnosed when total cholesterol was $>6.24 \mathrm{mmol} / 1(240 \mathrm{mg} / \mathrm{dl})$, LDL cholesterol $>4.14 \mathrm{mmol} / \mathrm{l}$ (160 mg/dl), HDL cholesterol $<1.02 \mathrm{mmol} / \mathrm{l}(40 \mathrm{mg} / \mathrm{dl})$ and triglycerides $>1.68 \mathrm{mmol} / \mathrm{l}(150 \mathrm{mg} / \mathrm{dl})(23)$, or when the patient was already receiving antidyslipidemia treatment.

Expression of Vla receptor $m R N A$ using quantitative realtime PCR (QRT-PCR). The total RNA of operated adrenal samples was isolated using the RNeasy kit (Qiagen, Valencia, CA, USA). RNA was then reverse-transcribed using the Prime Script 1st strand cDNA system (Takara Bio, Tokyo, Japan), and its cDNA products were subjected to QRT-PCR using the 7500 Fast Real-Time PCR system (Applied Biosystems, Foster City, CA, USA). The mRNA expression of the V1a receptor was normalized to glyceraldehyde-3-phosphate dehydrogenase (GAPDH). Oligonucleotide primers for V1aR and GAPDH were as follows: 5'-GATCGTGACGGCTTACATCG-3'/5'GCAGTGATGGTGATGGTAGG-3' for V1aR, and 5'-CAA CTACATGGTTTACATGTTC-3'/5'-GCCAGTGGACTC CACGAC-3' for GAPDH.

Assays. Urinary and plasma cortisols were measured by radioimmunoassay (RIA) using a commercial kit (Immunotech, Marseille, France). Plasma ACTH was measured by immunoradiometric assay (IRMA) (Mitsubishi Chemical, Tokyo, Japan) and DHEAS by RIA (Diagnostic Products Corp., Los Angeles, CA, USA).

Statistical analysis. Data are shown as the mean \pm SD. The difference between two groups was tested by the Student's t-test (normally distributed continuous variables) or the Mann-Whitney U test (abnormally distributed continuous variables). Comparisons of proportions were performed using the $\chi^{2}$ test. Correlations between HOMA-IR, cortisol response to vasopressin and plasma cortisol after dexamethasone were determined by Pearson's correlation analysis. $\mathrm{P}<0.05$ was considered statistically significant. SPSS software version 14.0 (SPSS Inc., Chicago, IL, USA) was used for statistical analysis.

\section{Results}

Vasopressin responders and non-responders in patients with subclinical Cushing's syndrome. Percentages of individual cortisol response to vasopressin in vasopressin responders and non-responders are shown in Fig. 1. The mean cortisol response to vasopressin was $109.7 \pm 44.3 \%$ in responders and $16.1 \pm 22.8 \%$ in non-responders.

Clinical and endocrinological differences between vasopressin responders and non-responders in patients with subclinical Cushing's syndome. Vasopressin responders and nonresponders had similar characteristics in terms of age, gender and BMI. However, vasopressin responders had a higher prevalence of bilateral nodule $(\mathrm{s})(\mathrm{P}<0.01)$, with 8 cases having bilateral nodules and 6 cases a unilateral nodule. The 8 patients with bilateral nodules were diagnosed as having AIMAH; 2 underwent unilateral adrenalectomy, demonstrating adrenal hyperplasia with pathological features. There was no significant difference between endocrinological data from the 


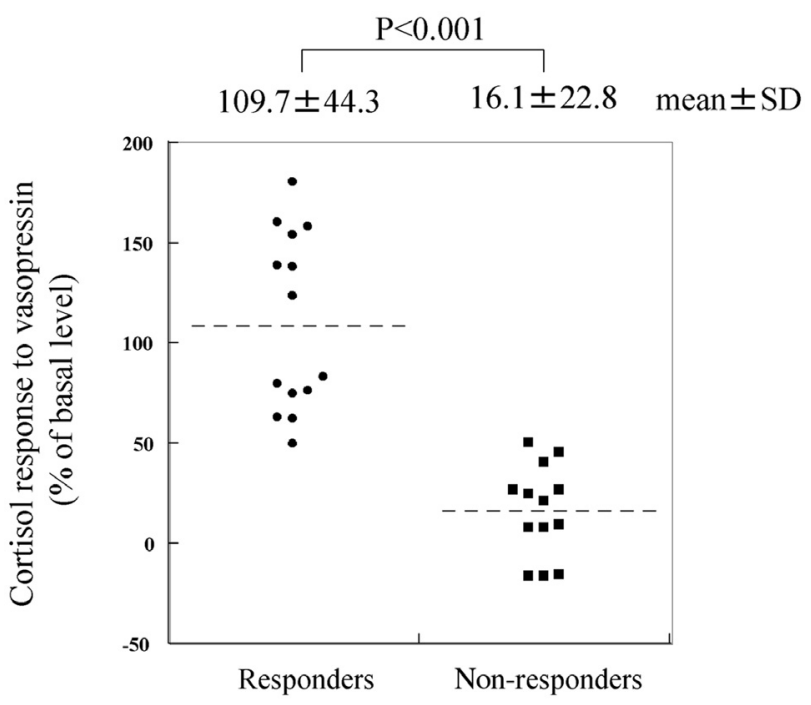

Figure 1. Plasma cortisol response to vasopressin in vasopressin responders and non-responders with subclinical CS. Data represent the \% of basal levels.

bilateral nodules (AIMAH) and the unilateral nodule (data not shown) in vasopressin responders with subclinical CS.

Endocrinological evaluation showed that vasopressin responders had significantly lower plasma cortisol levels than non-responders at midnight $(\mathrm{P}<0.05)$ as well as in the morning following overnight dexamethasone suppression at $1 \mathrm{mg}$ $(\mathrm{P}<0.05)$ (Table I).
Metabolic abnormalities in vasopressin responders and nonresponders. Metabolic abnormalities in vasopressin responders and non-responders are summarized in Table II. The prevalence of hypertension was significantly higher in vasopressin responders than in non-responders $(\mathrm{P}<0.05)$, as was systolic blood pressure $(\mathrm{P}<0.05)$. As for the prevalence of impaired glucose tolerance and dyslipidemia, the two groups had similar values, although vasopressin responders had lower autonomous cortisol secretion than non-responders. HbA1c $(\mathrm{P}=0.179)$ and HOMA-IR $(\mathrm{P}=0.185)$ tended to be higher in vasopressin responders than in non-responders.

We performed 75g-OGTT in 9 vasopressin responders and 8 non-responders not diagnosed as having diabetes mellitus (Fig. 2). Plasma glucose levels according to OGTT results were similar in vasopressin responders and non-responders, whereas plasma insulin levels were significantly higher at $60 \mathrm{~min}$ in vasopressin responders than in non-responders $(\mathrm{P}<0.05)$.

Correlation analysis (Fig. 3) revealed a significantly positive association between HOMA-IR and the cortisol response to vasopressin $(\mathrm{r}=0.671, \mathrm{P}<0.05)$. In contrast, no correlations between HOMA-IR and the cortisol response to vasopressin were found in non-responders (data not shown). There were also no associations between HOMA-IR and autonomous cortisol secretion in terms of plasma cortisol levels after 1 or $8 \mathrm{mg}$ dexamethasone, midnight plasma cortisol and urinary cortisol (data not shown).

Expression of Vla receptor $m R N A$ in vasopressin responders and non-responders using $Q R T-P C R$. In some resected adrenal

Table I. Endocrinological characteristics in vasopressin responders and non-responders.

\begin{tabular}{|c|c|c|c|}
\hline & Responders & Non-responders & P-value \\
\hline No. of patients & 14 & 13 & \\
\hline Age (years) & $59.0 \pm 10.9$ & $59.5 \pm 9.9$ & 0.941 \\
\hline Gender $(\mathrm{M} / \mathrm{F})$ & $6 / 8$ & $6 / 7$ & 0.863 \\
\hline $\mathrm{BMI}\left(\mathrm{kg} / \mathrm{m}^{2}\right)$ & $24.2 \pm 2.4$ & $23.8 \pm 3.6$ & 0.978 \\
\hline Bilateral/unilateral nodules & $8 / 6$ & $0 / 13$ & $\leq 0.01$ \\
\hline Plasma cortisol at 08:00 h $(\mathrm{nmol} / \mathrm{l})$ & $189.7 \pm 128.5$ & $283.5 \pm 112.4$ & 0.084 \\
\hline Plasma ACTH at 08:00 h (pmol/l) & $2.9 \pm 0.9$ & $3.2 \pm 0.6$ & 0.177 \\
\hline Midnight plasma cortisol (nmol/l) & $159.6 \pm 81.4$ & $197.8 \pm 49.6$ & $\leq 0.05$ \\
\hline Urinary cortisol (nmol/day) & $973.5 \pm 469.5$ & $1111.5 \pm 761.9$ & 0.930 \\
\hline Low DHEAS (\%) & $21.4(3 / 14)$ & $31.5(2 / 13)$ & 0.686 \\
\hline \multicolumn{4}{|c|}{ Plasma cortisol after $1 \mathrm{mg}$ dexamethasone } \\
\hline Overnight suppression (nmol/l) & $122.3 \pm 91.0$ & $176.4 \pm 102.0$ & $\leq 0.05$ \\
\hline \multicolumn{4}{|c|}{ Plasma cortisol after $8 \mathrm{mg}$ dexamethasone } \\
\hline Overnight suppression (nmol/l) & $148.8 \pm 91.8$ & $196.3 \pm 105.1$ & 0.171 \\
\hline
\end{tabular}

Values are the mean \pm SD. 
Table II. Metabolic abnormalities in vasopressin responders and non-responders.

\begin{tabular}{|c|c|c|c|}
\hline & Responders & Non-responders & P-value \\
\hline No. of patients & 14 & 13 & \\
\hline Hypertension (\%) & $92.8(13 / 1)$ & $53.8(7 / 6)$ & $\leq 0.05$ \\
\hline Systolic blood pressure (mm Hg) & $151.2 \pm 10.9$ & $134.9 \pm 19.2$ & $\leq 0.05$ \\
\hline Diastolic blood pressure (mm Hg) & $89.9 \pm 6.3$ & $82.9 \pm 10.0$ & 0.093 \\
\hline Plasma renin activity supine $(\mathrm{ng} / \mathrm{ml} / \mathrm{h})$ & $0.6 \pm 0.5$ & $1.2 \pm 0.7$ & $\leq 0.05$ \\
\hline Plasma aldosterone supine (pmol/l) & $271.7 \pm 281.9$ & $293.8 \pm 291.8$ & 0.553 \\
\hline DM or IGT $(\%)$ & $64.2(9 / 5)$ & $53.8(7 / 6)$ & 0.581 \\
\hline $\operatorname{HbA1c}(\%)$ & $5.8 \pm 1.2$ & $5.3 \pm 0.7$ & 0.179 \\
\hline Fasting plasma glucose (mmol/l) & $5.4 \pm 1.0$ & $5.1 \pm 0.9$ & 0.277 \\
\hline HOMA-IR & $1.5 \pm 0.6$ & $1.1 \pm 0.5$ & 0.185 \\
\hline Hyperlipidemia (\%) & $50.0(7 / 7)$ & $38.4(5 / 8)$ & 0.546 \\
\hline LDL cholesterol (mmol/l) & $3.1 \pm 0.5$ & $3.2 \pm 1.0$ & 0.790 \\
\hline Triglycerides (mmol/l) & $1.2 \pm 0.6$ & $1.2 \pm 0.6$ & 0.817 \\
\hline HDL cholesterol (mmol/l) & $1.4 \pm 0.3$ & $1.4 \pm 0.4$ & 0.576 \\
\hline
\end{tabular}

Values are the mean \pm SD.

A

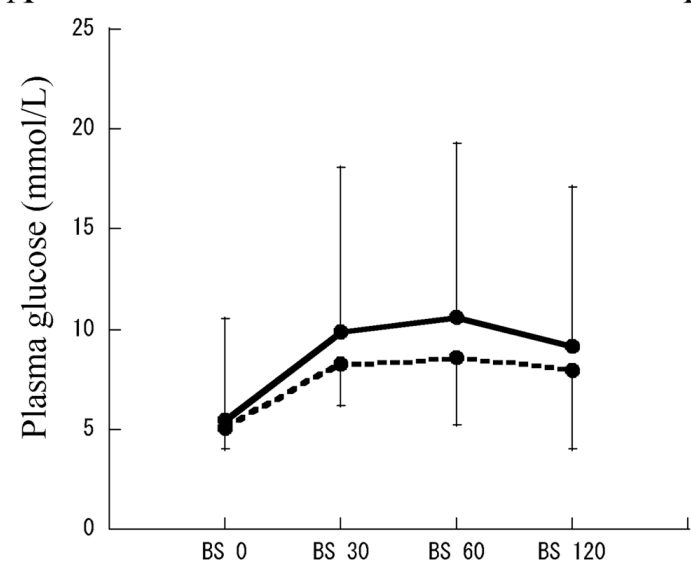

B

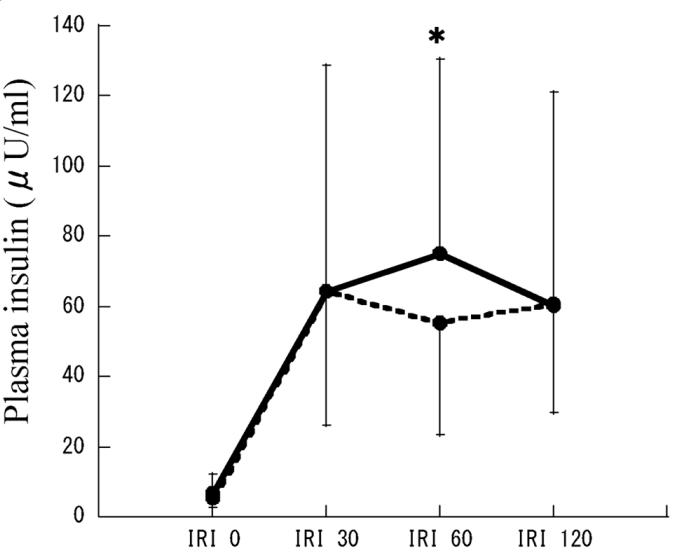

Figure 2. 75g-OGTT in vasopressin responders and non-responders. (A) Plasma glucose; (B) Insulin. Bold line, vasopressin responders; striped line, nonresponders. Each point and vertical bar represents mean $\pm \mathrm{SD}$. ${ }^{*} \mathrm{P}<0.05$.

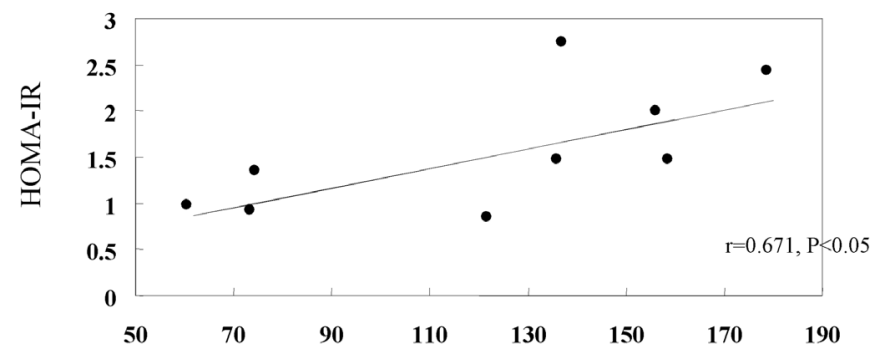

Figure 3. Correlation between HOMA-IR and cortisol response to vasopressin in vasopressin responders.

glands, we measured V1a receptor mRNA using QRT-PCR (Fig. 4). The levels of V1aR mRNA (ratio of V1aR/GAPDH) in vasopressin responders were 63.6 and 20.6 in patients with
AIMAH, 13.3 in those with a unilateral adenoma and 18.8 in those with a non-adenoma lesion. In non-respondrers, V1a receptor mRNA levels were 6.0,3.8 and 2.4 in patients with a unilateral adenoma due to subclinical CS and 6.0 in those with a unilateral adenoma due to overt CS. V1a receptor mRNA levels were higher in vasopressin responders than in non-responders. Notably, both the adenoma lesion and its non-adenoma counterpart had similar high levels of V1a receptor mRNA in vasopressin responders with CS.

\section{Discussion}

In patients with subclinical CS, we found that vasopressin responders showed a significantly higher frequency of hypertensive complications and a similarly high prevalence of impaired glucose tolerance and dyslipidemia, although they 


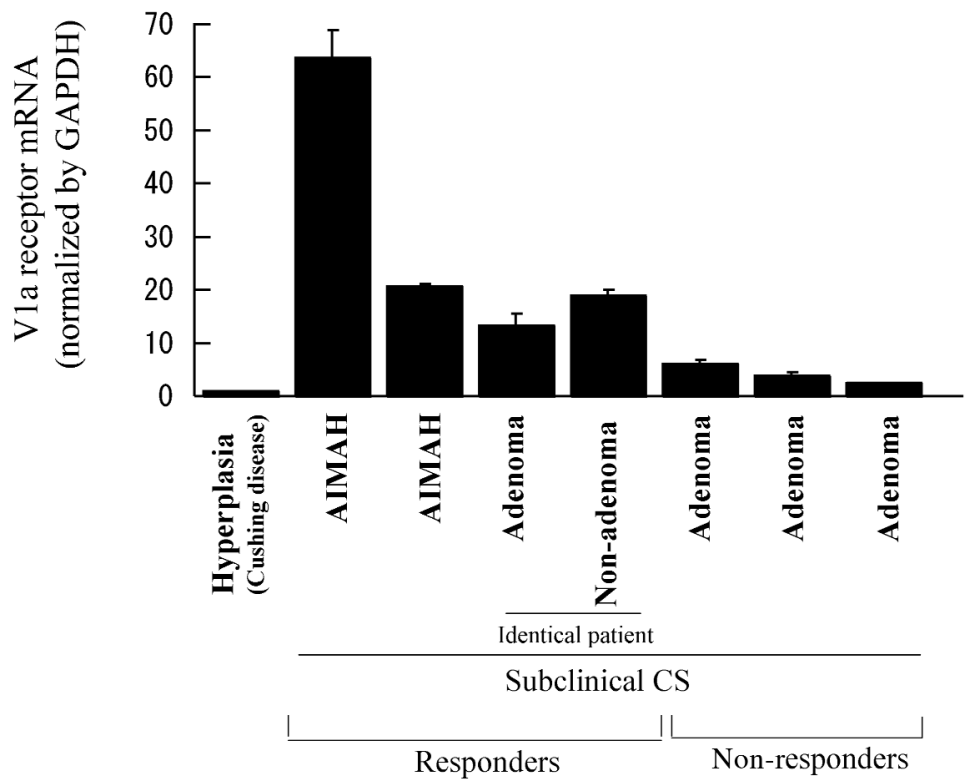

Figure 4. Expression of V1a receptor mRNA using quantitative real-time PCR in vasopressin responders and non-responders. The level of V1a receptor was normalized to GAPDH

had a significantly lower autonomous secretion of cortisol than non-responders. The cortisol response to vasopressin had a significantly positive association with HOMA-IR in vasopressin responders with high expression levels of V1a receptor mRNA.

Of note, the dexamethasone suppression test revealed lower plasma cortisol in vasopressin responders than in nonresponders among patients with subclinical CS, a finding that suggests very low autonomous cortisol secretion in vasopressin responders. The pathophysiology of this lower autonomous secretion of cortisol was not clarified in the present study. It is known that the majority of AIMAH patients are vasopressin responders $(4-7,9)$. AIMAH patients have been reported to have low levels of autonomous cortisol secretion due to insufficient steroid synthesis (24). In the present study, there was no significant difference between subclinical CS vasopressin responders with bilateral nodules (AIMAH) and those with unilateral nodules. It is possible that vasopressin responders with unilateral nodules have a low level of cortisol secretion, as observed in AIMAH cases.

One of the notable results of this study was that vasopressin responders, who had decreased autonomous cortisol secretion, showed a significantly higher frequency of hypertensive complications and a similarly high prevalence of impaired glucose tolerance and dyslipidemia complications in comparison with non-responders. According to 75g-OGTT, vasopressin responders had hyperinsulemia and insulin resistance, which was significantly correlated with cortisol response to vasopressin. Since hypertension, impaired glucose tolerance, dyslipidemia, hyperinsulemia and insulin resistance have been reported to be involved in metabolic syndrome with a high risk of cardiovascular disease $(25,26)$, long follow-ups of vasopressin responders with subclinical CS should be carried out.

We analyzed V1a receptor mRNA in adrenal glands using QRT-PCR. Although only a few patients underwent surgery, $\mathrm{V} 1 \mathrm{a}$ receptor mRNA in vasopressin responders was higher than in non-responders, with the highest expression in AIMAH patients. These findings and those of previous reports (10-15) suggest that the overexpression of $\mathrm{V} 1$ a receptor could explain the cortisol hyper-response to vasopressin in vasopressin responders, especially those with AIMAH. Overexpression of the V1a receptor may be associated with progression in the adrenal nodules, since adrenal cells with eutopic overexpression of the V1a receptor in patients with AIMAH were reportedly involved in cell regeneration (11). Christopoulos et al (27) hypothesized that V1a receptor overexpression represented the underlying pathogenetic mechanism in AIMAH, rather than resulting from an epiphenomenon of uncontrolled cell proliferation. In the present study, both the adenoma and its non-adenoma counterpart in the same patient with adrenal hyperresponsiveness of plasma cortisol to vasopressin had similar high levels of V1a receptor mRNA. These data suggest that overexpression of $\mathrm{V} 1 \mathrm{a}$ receptor in the adrenal cortex is a factor promoting the development of cortisol-secreting adrenal nodule(s). However, how existing V1a receptor overexpression causes adrenal nodules, whether it is acquired or congenital, and what its causative underlying mechanism is have yet to be clarified. In light of this, reports on familial AIMAH are of interest $(28,29)$, and further studies focusing on the mechanisms of $\mathrm{V} 1 \mathrm{a}$ receptor overexpression in vasopressin responders should be conducted.

The pathophysiology of the association between insulin resistance and vasopressin response is not explained in the present study. It has been reported that patients with preclinical CS due to AIMAH have excessive secretion of mineralocorticoid hormones such as 11-deoxycorticosterone (DOC), corticosterone and 18-hydroxydeoxycorticosterone $(30,31)$. These mineralocorticoid hormones were not measured in the present study. Recent studies suggest that mineralocorticoids are involved in insulin resistance as well as in hypertension (32-34). Whether mineralocorticoid hormones are increased in vasopressin responders is an interesting 
subject for future investigation. The significantly low levels of plasma renin in vasopressin responders in the present study support this hypothesis.

It has been reported that vasopressin responders demonstrate the presence of other ectopic and eutopic receptors, such as $\mathrm{B}$-adrenergic, GIP, $\mathrm{LH} / \mathrm{hCG}$ and serotonin receptors. The possibility that hormones besides vasopressin influence metabolic abnormalities cannot be ruled out. These additional putative features also merit future investigation.

In conclusion, vasopressin responders with subclinical CS had decreased autonomous cotisol secretion, but a high prevalence of hypertension associated with insulin resistance.

\section{Acknowledgements}

The authors wish to thank Professor Sho Yoshida for his valuable advice, and Ms. Kayo Suzuki for her excellent assistance.

\section{References}

1. Birnbaumer M, Seibold A, Gilbert S, et al: Molecular cloning of the receptor for human antidiuretic hormone. Nature 357: 333-335, 1992

2. De Keyzer Y, Auzan C, Lenne F, et al: Cloning and characterization of the human V3 pituitary vasopressin receptor. FEBS Lett 356: 215-220, 1994.

3. Perraudin V, Delarue C, Lefebvre H, Contesse V, Kuhn JM and Vaudry H: Vasopressin stimulates cortisol secretion from human adrenocortical tissue through activation of V1 receptors. J Clin Endocrinol Metab 76: 1522-1528, 1993.

4. Horiba N, Suda T, Aiba M, et al: Lysine vasopressin stimulation of cortisol secretion in patients with adrenocorticotropin-independent macronodular adrenal hyperplasia. J Clin Endocrinol Metab 80: 2336-2341, 1995.

5. Perraudin V, Delarue C, De Keyzer Y, et al: Vasopressinresponsive adrenocortical tumor in a mild Cushing's syndrome: in vivo and in vitro studies. J Clin Endocrinol Metab 80: 2661-2667, 1995.

6. Lacroix A, Tremblay J, Touyz RM, et al: Abnormal adrenal and vascular responses to vasopressin mediated by a V1-vasopressin receptor in a patient with adrenocorticotropin-independent macronodular adrenal hyperplasia, Cushing's syndrome, and orthostatic hypotension. J Clin Endocrinol Metab 82: 2414-2422, 1997.

7. Iida K, Kaji H, Matsumoto H, et al: Adrenocorticotrophinindependent macronodular adrenal hyperplasia in a patient with lysine vasopressin responsiveness but insensitivity to gastric inhibitory polypeptide. Clin Endocrinol (Oxf) 47: 739-745, 1997

8. Reznik Y, Lefebvre H, Rohmer V, et al: Aberrant adrenal sensitivity to multiple ligands in unilateral incidentaloma with subclinical autonomous cortisol hypersecretion: a prospective clinical study. Clin Endocrinol (Oxf) 61: 311-319, 2004.

9. Suzuki S, Uchida D, Koide H, et al: Hyper-responsiveness of adrenal gland to vasopressin resulting in enhanced plasma cortisol in patients with adrenal nodule(s). Peptides (In press).

10. Daidoh H, Morita H, Hanafusa J, et al: In vivo and in vitro effects of AVP and V1a receptor antagonist on Cushing's syndrome due to ACTH-independent bilateral macronodular adrenocortical hyperplasia. Clin Endocrinol (Oxf) 49: 403-409, 1998.

11. Arnaldi G, Gasc JM, De Keyzer Y, et al: Variable expression of the V1 vasopressin receptor modulates the phenotypic response of steroid-secreting adrenocortical tumors. J Clin Endocrinol Metab 83: 2029-2035, 1998.

12. Mircescu H, Jilwan J, N'Diaye N, et al: Are ectopic or abnormal membrane hormone receptors frequently present in adrenal Cushing's syndrome? J Clin Endocrinol Metab 85: 3531-3536, 2000 .

13. Lacroix A, Ndiaye N, Tremblay J and Hamet P: Ectopic and abnormal hormone receptors in adrenal Cushing's syndrome. Endocr Rev 22: 75-110, 2001.
14. Mune T, Murase H, Yamakita N, et al: Eutopic overexpression of vasopressin vla receptor in adrenocorticotropin-independent macronodular adrenal hyperplasia. J Clin Endocrinol Metab 87: 5706-5713, 2002.

15. Tatsuno I, Uchida D, Tanaka T, et al: Vasopressin responsiveness of subclinical Cushing's syndrome due to ACTH-independent macronodular adrenocortical hyperplasia. Clin Endocrinol (Oxf) 60: 192-200, 2004.

16. Arnaldi G, Angeli A, Atkinson AB, et al: Diagnosis and complications of Cushing's syndrome: a consensus statement. J Clin Endocrinol Metab 88: 5593-5602, 2003.

17. Christopoulos S, Bourdeau I and Lacroix A: Clinical and subclinical ACTH-independent macronodular adrenal hyperplasia and aberrant hormone receptors. Horm Res 64: 119-131, 2005.

18. Newell-Price J, Bertagna X, Grossman AB and Nieman LK: Cushing's syndrome. Lancet 367: 1605-1617, 2006.

19. Kirkendall WM, Burton AC, Epstein FH and Freis ED: Recommendations for human blood pressure determination by sphygmomanometers. Circulation 36: 980-988, 1967.

20. Chobanian AV, Bakris GL, Black HR, et al: The seventh report of the Joint National Committee on prevention, detection, evaluation, and treatment of high blood pressure: the JNC 7 report. JAMA 289: 2560-2572, 2003.

21. Gabir MM, Hanson RL, Dabelea D, et al: The 1997 American Diabetes Association and 1999 World Health Organization criteria for hyperglycemia in the diagnosis and prediction of diabetes. Diabetes Care 23: 1108-1112, 2000.

22. Matthews DR, Hosker JP, Rudenski AS, Naylor BA, Treacher DF and Turner RC: Homeostasis model assessment: insulin resistance and beta-cell function from fasting plasma glucose and insulin concentrations in man. Diabetologia 28: 412-419, 1985.

23. Executive Summary of The Third Report of The National Cholesterol Education Program (NCEP) Expert Panel on Detection, Evaluation And Treatment of High Blood Cholesterol In Adults (Adult Treatment Panel III). JAMA 285: 2486-2497, 2001.

24. Wada N, Kubo M, Kijima H, et al: Adrenocorticotropinindependent bilateral macronodular adrenocortical hyperplasia: immunohistochemical studies of steroidogenic enzymes and post-operative course in two men. Eur J Endocrinol 134: 583-587, 1996.

25. Reaven GM: Banting lecture 1988. Role of insulin resistance in human disease. Diabetes 37: 1595-1607, 1988

26. Kashyap SR and Defronzo RA: The insulin resistance syndrome: physiological considerations. Diab Vasc Dis Res 4: 13-19, 2007.

27. Christopoulos S, Bourdeau I and Lacroix A: Aberrant expression of hormone receptors in adrenal Cushing's syndrome. Pituitary 7: 225-235, 2004.

28. Findlay JC, Sheeler LR, Engeland WC and Aron DC: Familial adrenocorticotropin-independent Cushing's syndrome with bilateral macronodular adrenal hyperplasia. J Clin Endocrinol Metab 76: 189-191, 1993.

29. Vezzosi D, Cartier D, Regnier C, et al: Familial adrenocorticotropin-independent macronodular adrenal hyperplasia with aberrant serotonin and vasopressin adrenal receptors. Eur J Endocrinol 156: 21-31, 2007.

30. Hayashi Y, Takeda Y, Kaneko K, et al: A case of Cushing's syndrome due to ACTH-independent bilateral macronodular hyperplasia associated with excessive secretion of mineralocorticoids. Endocr J 45: 485-491, 1998.

31. Wada S, Kitahama S, Togashi A, Inoue K, Iitaka M and Katayama S: Preclinical Cushing's syndrome due to ACTHindependent bilateral macronodular adrenocortical hyperplasia with excessive secretion of 18-hydroxydeoxycorticosterone and corticosterone. Intern Med 41: 304-308, 2002.

32. Hernandez N, Torres SH, De Sanctis JB and Sosa A: Metabolic changes in DOCA-salt hypertensive rats. Res Commun Mol Pathol Pharmacol 108: 201-211, 2000.

33. Caprio M, Feve B, Claes A, Viengchareun S, Lombes M and Zennaro MC: Pivotal role of the mineralocorticoid receptor in corticosteroid-induced adipogenesis. FASEB J 21: 2185-2194, 2007.

34. Hitomi H, Kiyomoto H, Nishiyama A, et al: Aldosterone suppresses insulin signaling via the downregulation of insulin receptor substrate-1 in vascular smooth muscle cells. Hypertension 50: 750-755, 2007. 